\title{
Light-Activated Heterostructured Nanomaterials for Antibacterial Applications
}

\author{
Chinmaya Mutalik ${ }^{1}$, Di-Yan Wang ${ }^{2,3}$, Dyah Ika Krisnawati ${ }^{4}$, Achmad Jazidie ${ }^{5,6}$, \\ Sibidou Yougbare ${ }^{1}$ (D) and Tsung-Rong Kuo ${ }^{1,7, *(\mathbb{D})}$ \\ 1 International Ph.D. Program in Biomedical Engineering, College of Biomedical Engineering, Taipei Medical \\ University, Taipei 11031, Taiwan; cmutalik41@gmail.com (C.M.); d845107003@tmu.edu.tw (S.Y.) \\ 2 Department of Chemistry, Tunghai University, Taichung 40704, Taiwan; diyanwang@thu.edu.tw \\ 3 Center for Science and Technology, Tunghai University, Taichung 40704, Taiwan \\ 4 Dharma Husada Nursing Academy, Kediri, East Java 64114, Indonesia; dyahkrisna77@gmail.com \\ 5 Department of Electrical Engineering, Institut Teknologi Sepuluh Nopember, Surabaya 60111, Indonesia; \\ rektor@unusa.ac.id \\ 6 University Nahdlatul Ulama Surabaya, Surabaya 60111, Indonesia \\ 7 Graduate Institute of Nanomedicine and Medical Engineering, College of Biomedical Engineering, Taipei \\ Medical University, Taipei 11031, Taiwan \\ * Correspondence: trkuo@tmu.edu.tw
}

Received: 2 March 2020; Accepted: 27 March 2020; Published: 30 March 2020

check for updates

\begin{abstract}
An outbreak of a bacterial contagion is a critical threat for human health worldwide. Recently, light-activated heterostructured nanomaterials (LAHNs) have shown potential as antibacterial agents, owing to their unique structural and optical properties. Many investigations have revealed that heterostructured nanomaterials are potential antibacterial agents under light irradiation. In this review, we summarize recent developments of light-activated antibacterial agents using heterostructured nanomaterials and specifically categorized those agents based on their various light harvesters. The detailed antibacterial mechanisms are also addressed. With the achievements of LAHNs as antibacterial agents, we further discuss the challenges and opportunities for their future clinical applications.
\end{abstract}

Keywords: heterostructured nanomaterial; antibacterial agent; antibacterial mechanism; reactive oxygen species; light-activated; synergistic effect

\section{Introduction}

Antibacterial studies have become more significant because of the increased of multidrug-resistant (MDR) bacteria in this era [1-10]. Various mechanisms can stimulate antibacterial resistance, including overuse of antibiotics and the delivery of bacteria by different routes [11-13]. A recent report indicates that by 2050, antibacterial resistance will be a tremendous public health threat with the potential to cause the death of ten million people each year [14]. Therefore, development of new types of antibacterial agents against MDR bacteria is an urgent task. The development of new antibacterial agents inspired the researchers for the investigation of nanomaterials which can eliminate MDR bacteria without the help of antibiotics [15-19].

Nanomaterials-including metals, metal oxide, semiconductors and polymers-have been extensively studied for applications in nanoscience and nanotechnology, due to their superior chemical and physical properties [20-35]. Among nanomaterials, the heterostructured nanomaterials have shown unique optical properties, including the increase of light absorption and the extension of absorption region [36-41]. Recently, great advancements have been reported in the application of LAHNs as antibacterial agents. With the rise of light absorption and the extension of absorption 
region, heterostructured nanomaterials have shown superior antibacterial activity, based on reactive oxygen species (ROS) generation under light illumination [42-48]. The emphasis of this review is on the mechanism study of light-induced ROS generation from heterostructured nanomaterials by synergistic effect. Recent achievements with the uses of LAHNs as antibacterial agents are classified by their various light harvesters. Finally, challenges and perspectives for LAHNs as antibacterial agents are also provided.

\section{Antibacterial Nanomaterials Based on Light-induced ROS Generation}

Titanium dioxide $\left(\mathrm{TiO}_{2}\right)$ materials have been found to possess remarkable biocompatibility and low cell toxicity with significant antibacterial activity [49-58]. Recently, $\mathrm{TiO}_{2}$-based nanomaterials were popular materials with substantial amount of antibacterial activities, and their antibacterial activities could be further enhanced by light irradiations with various wavelengths, including ultraviolet (UV) light, visible light and near-infrared (NIR) light due to the increase of ROS generation [59-67]. For example, with UV light irradiation, heterostructured $\mathrm{Ag}-\mathrm{TiO}_{2}$ nanoparticles have displayed higher bactericidal activity compared to that of only UV irradiation, Ag nanoparticles under UV irradiation or $\mathrm{TiO}_{2}$ nanoparticles under UV irradiation (Figure 1) [68]. With UV light illumination, the augmentation of bactericidal activity of hybrid $\mathrm{Ag}-\mathrm{TiO}_{2}$ nanoparticles indicated that $\mathrm{Ag}$ nanoparticles loaded onto $\mathrm{TiO}_{2}$ nanoparticles served as electron traps to prevent recombination of electron and hole in hybrid $\mathrm{Ag}-\mathrm{TiO}_{2}$ nanoparticles. The photo-exited electrons were generated and then transferred to $\mathrm{Ag}$ nanoparticles to extend the life of electron-hole pairs. In the system of hybrid $\mathrm{Ag}-\mathrm{TiO}_{2}$ nanoparticles, the increases of electron-hole pairs enhanced ROS generation for the destruction of bacterial membrane or DNA [69-74]. In the work, hybrid $\mathrm{Ag}-\mathrm{TiO}_{2}$ nanoparticles provided more effective bactericides with light irradiations; however, the uses of hybrid $\mathrm{Ag}-\mathrm{TiO}_{2}$ nanoparticles as an antibacterial agent were challenging in practical application due to their high cytotoxicity and facile accumulation in tissues and organs.

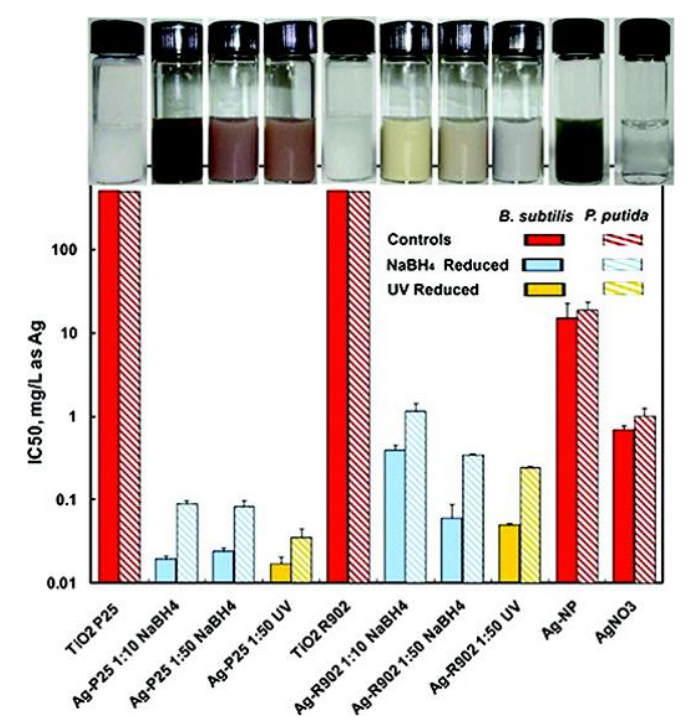

Figure 1. IC50 values of different hybrid $\mathrm{Ag}-\mathrm{TiO}_{2}$ nanoparticles with and without UV light irradiations. $\mathrm{TiO}_{2}$ P25 (Degussa P25) and $\mathrm{TiO}_{2}$ R-902 (DuPont Ti-Pure R-902) were two commercial $\mathrm{TiO}_{2}$ nanoparticles. Two different molar ratios of $\mathrm{AgNO}_{3}$ and $\mathrm{TiO}_{2}$ including 1:10 and 1:50 were respectively employed to prepare Ag nanoparticles deposited onto the $\mathrm{TiO}_{2}$ nanoparticles by $\mathrm{NaBH}_{4}$ reduction and UV photoreduction to form the samples of Ag-P25 1:10 NaBH 4, Ag-P25 1:50 NaBH 4 , Ag-P25 1:50 UV, Ag-R902 1:10 NaBH 4 , Ag-R902 1:50 NaBH 4 and Ag-R902 1:50 UV. Ag nanoparticles and AgNO 3 were purchased from QuantumSphere, Inc. Reproduced with permission from ref. [68]. Copyright (C) 2011, American Chemical Society. 
Nanocomposites of $\mathrm{AgVO}_{3}$ quantum dots (QDs) deposited onto $\mathrm{TiO}_{2}$ nanospheres $\left(\mathrm{TiO}_{2} / \mathrm{AgVO}_{3}\right)$ have shown high-performance photocatalytic capability with visible light irradiation [75-77]. $\mathrm{TiO}_{2} / \mathrm{AgVO}_{3}$ nanocomposites incubated with $\mathrm{E}$. coli have been investigated to study their light-induced bacterial inactivation with illumination of visible light. In the control experiment, after visible light irradiation over $120 \mathrm{~min}, \mathrm{TiO}_{2}$ nanospheres were inactivated only $0.13 \log$ of E. coli. With the use of $\mathrm{TiO}_{2} / \mathrm{AgVO}_{3}$ nanocomposites as photocatalysts, all of $E$. coli were killed under visible light irradiation over 120 min. After $\mathrm{TiO}_{2} / \mathrm{AgVO}_{3}$ nanocomposites incubated with $E$. coli, with visible light irradiation; the shape of $E$. coli was destroyed. Moreover, there were no obvious changes of bacterial inactivity of $\mathrm{TiO}_{2} / \mathrm{AgVO}_{3}$ nanocomposites after three cycling antibacterial tests under visible light irradiation indicating that $\mathrm{TiO}_{2} / \mathrm{AgVO}_{3}$ nanocomposites were good photocatalysts with superior stability. For the photocatalytic disinfection mechanism, $\mathrm{AgVO}_{3} \mathrm{QDs}$ were excited to offer light-induced pairs of electrons and holes with visible light illumination and then the light-induced electrons located in the conduction band of $\mathrm{AgVO}_{3}$ QDs were easily delivered to the conduction band of $\mathrm{TiO}_{2}$ (Figure 2). The light-induced electrons in the conduction band of $\mathrm{TiO}_{2}$ could react with oxygen in medium to form $\cdot \mathrm{O}_{2}{ }^{-}$. Moreover, the holes located in the valence band of $\mathrm{AgVO}_{3} \mathrm{QDs}$ could be delivered to their surface to inhibit the growth of $E$. coli. To sum up, the light-induced electron-hole pairs in $\mathrm{TiO}_{2} / \mathrm{AgVO}_{3}$ nanocomposites were efficiently separated to improve the light-induce antibacterial activity of $E$. coli.

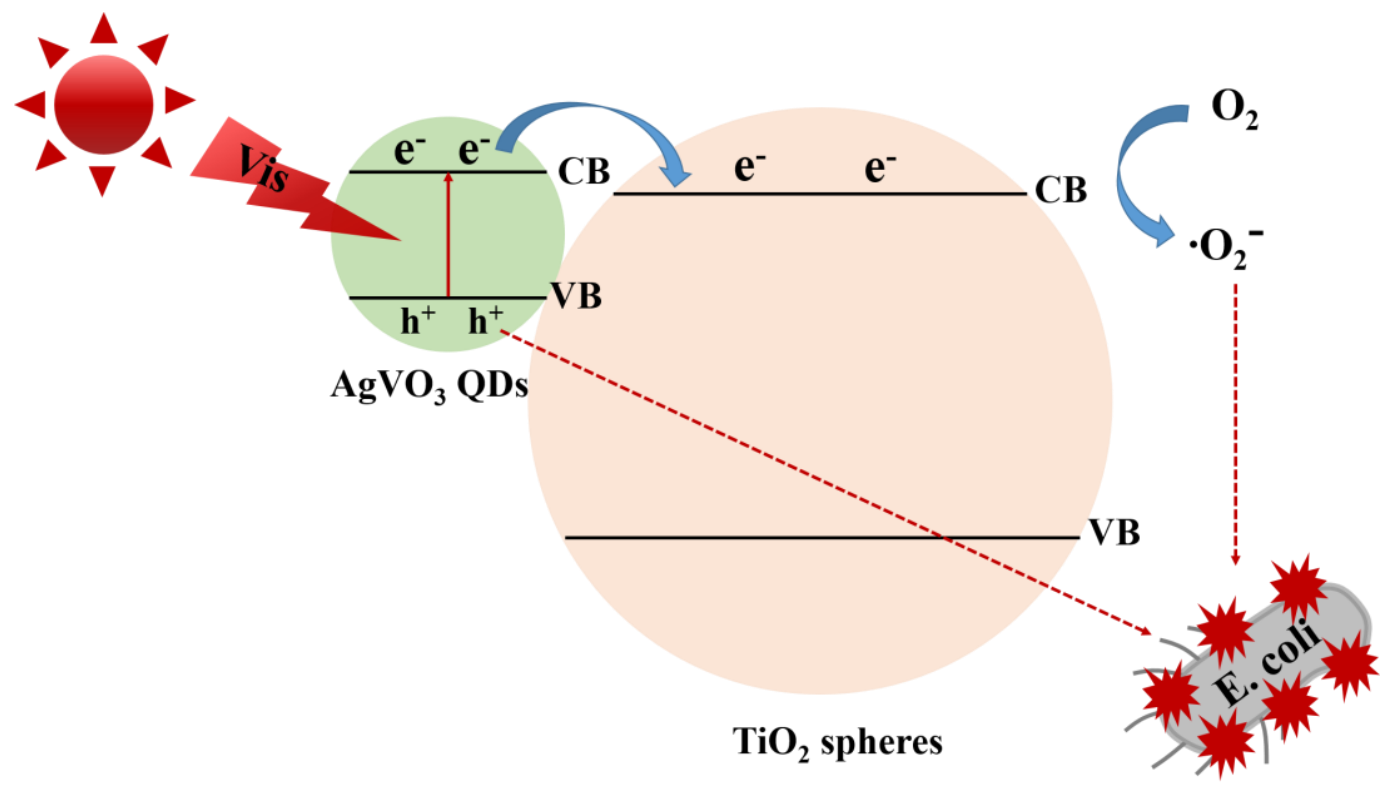

Figure 2. Antibacterial mechanism of $\mathrm{TiO}_{2} / \mathrm{AgVO}_{3}$ nanocomposites with visible light illumination. Reproduced with permission from ref. [75]. Copyright (C) 2019, Elsevier.

Natural polymers of cellulose are intensively used in daily life [78-80]. However, the application of cellulose has been limited, due to its susceptibility to microorganism growth. In recent advancements, a simple sol-gel approach has been used to conjugate the cellulose scaffold with $\mathrm{Ag} / \mathrm{TiO} \mathrm{O}_{2}$ nanoparticles $\left(\mathrm{Ag} / \mathrm{TiO}_{2} /\right.$ cellulose) against bacteria (Figure 3) [81]. The antibacterial activities of nanocomposite film of $\mathrm{Ag} / \mathrm{TiO}_{2} /$ cellulose, film of pristine cellulose and nanocomposite film of $\mathrm{TiO}_{2} /$ cellulose have been investigated with $E$. coli with and without UV light irradiation. The bactericidal performance of the nanocomposite film of $\mathrm{Ag} / \mathrm{TiO}_{2} /$ cellulose with $\mathrm{Ag}$ content of $0.030 \mathrm{wt} \%$ has shown the best $99.9 \%$ inactivation of E. coli with UV light illumination. The results suggest that the nanocomposite film of $\mathrm{Ag} / \mathrm{TiO}_{2} /$ cellulose exhibit superior bactericidal performance against $E$. coli because of the synergistic effect of Ag nanoparticles and anatase $\mathrm{TiO}_{2}$ nanoparticles. Under UV light irradiation, $\mathrm{TiO}_{2}$ nanoparticles may generate ROS-including $\cdot \mathrm{OH}, \cdot \mathrm{O}_{2}{ }^{-}$and $\mathrm{H}_{2} \mathrm{O}_{2}-$ prompting bacterial death. Moreover, Ag nanoparticles may capture electrons, restraining the recombination of photon-induced 
electron/hole pairs for the increase of ROS formation. Overall, the bactericidal performance of the nanocomposite film of $\mathrm{Ag} / \mathrm{TiO}_{2} /$ cellulose was significantly enhanced under UV light irradiation.

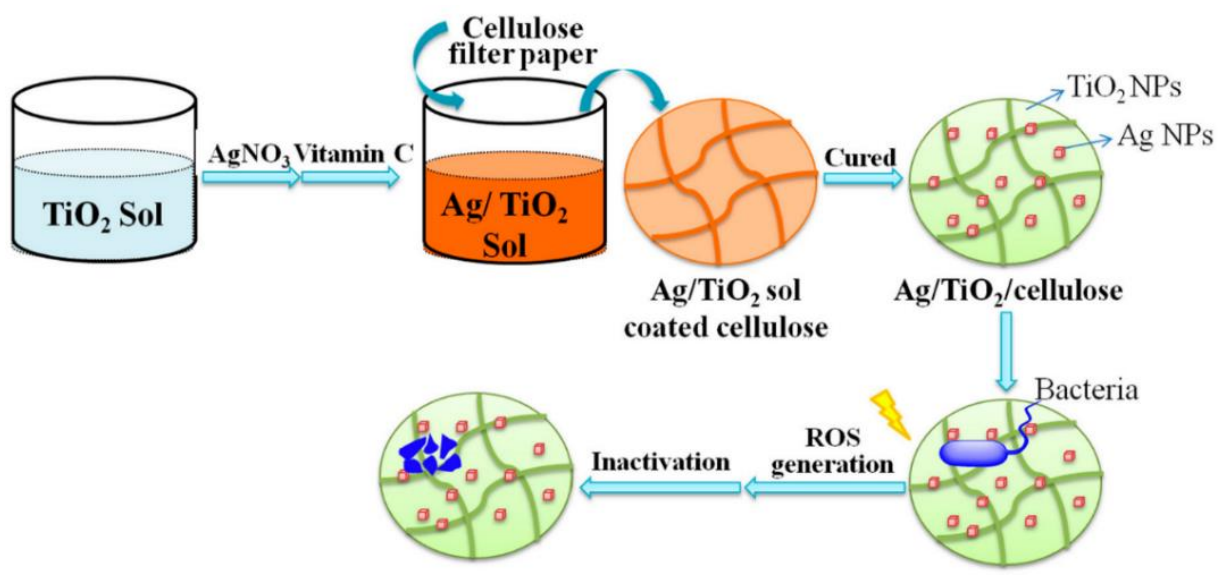

Figure 3. Schematic illustration of preparation of the nanocomposite film of $\mathrm{Ag} / \mathrm{TiO}_{2} / \mathrm{cellul}$ lose and its antibacterial mechanism. Reproduced with permission from ref. [81]. Copyright (C) 2018, MDPI.

$\mathrm{Au}-\mathrm{TiO}_{2}$ nanocomposites embedded into a degradable and antibacterial sodium alginate films have been developed by food packaging industries against bacteria [82]. Sodium alginate/ $\mathrm{Au}-\mathrm{TiO}_{2}$ nanocomposite (SAT) films were enabled to absorb light form UV to visible wavelength and to improve their hydrophilicity and shape stability. As shown in Figure 4, both sodium alginate/ $/ \mathrm{TiO}_{2}$ nanocomposite (ST) films and SAT films exhibit distinct antibacterial activities for S. aureus and $E$. coli in dark. With the use of SAT films, $90 \%$ of S. aureus and $97.1 \%$ E. coli were killed without light illumination, respectively. However, after light illumination for $20 \mathrm{~min}$, the antibacterial abilities of SAT films were respectively improved $\sim 60 \%$ and $~ 50 \%$ for S. aureus and E. coli. The improvement of antibacterial abilities of SAT films may be attributed to that the nanocomposites of $\mathrm{Au}-\mathrm{TiO}_{2}$ increased light absorption and transfer capability due to their plasmonic effect. The plasmonic Au nanoparticles in SAT films may harvest light to produce light-induced photons for the increase of ROS to kill bacteria.

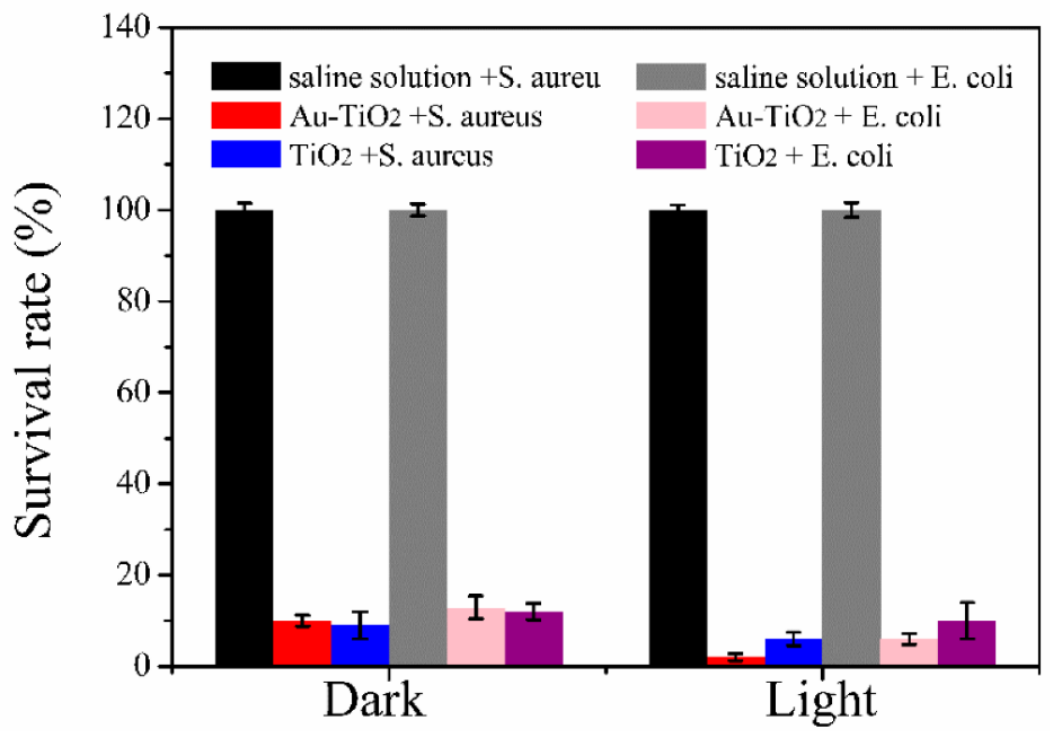

Figure 4. Antibacterial activities of saline solution, sodium alginate $/ \mathrm{TiO}_{2}$ nanocomposite (ST) film and sodium alginate/ $\mathrm{Au}-\mathrm{TiO}_{2}$ nanocomposite (SAT) film for S. aureus and E. coli with and without visible light illumination, respectively. Reproduced with permission from ref. [82]. Copyright (C) 2018, MDPI. 
The nanocomposites of lithium-titanate $\left(\mathrm{Li}-\mathrm{TiO}_{2}\right)$ in the low-density polyethylene (LDPE) matrix have shown a significant increase in killing efficiency for S. aureus with visible light illumination [83]. In the heterostructured nanocomposites of $\mathrm{Li}_{-} \mathrm{TiO}_{2} / \mathrm{LDPE}$, the oxygen vacancies of $\mathrm{Ti}^{3+}$ and interaction of $\mathrm{Li}-\mathrm{O}-\mathrm{Ti}$ bond reduced the band gap of $\mathrm{TiO}_{2}$ nanoparticles, resulting in their response to visible light (Figure 5). LDPE alone did not show any antibacterial activity for S. aureus. With the dopant

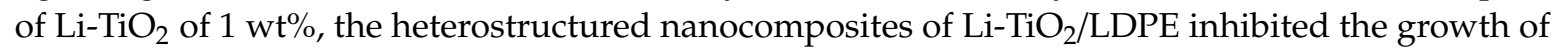
S. aureus by $94 \%$ after visible light irradiation for $6 \mathrm{~h}$, then raised the inhibition rate to $99 \%$ within $12 \mathrm{~h}$ under visible light irradiation. From the results of the scavenger test, the intensified bactericidal effect of the heterostructured nanocomposites of $\mathrm{Li}-\mathrm{TiO}_{2} / \mathrm{LDPE}$ were ascribed to the productions of powerful oxidants including $\cdot \mathrm{OH}$ and $\cdot \mathrm{O}_{2}{ }^{-}$under visible light irradiation. These powerful oxidants may particularly react with the polyunsaturated phospholipid composition of the bacterial membrane to form water and carbon dioxide.

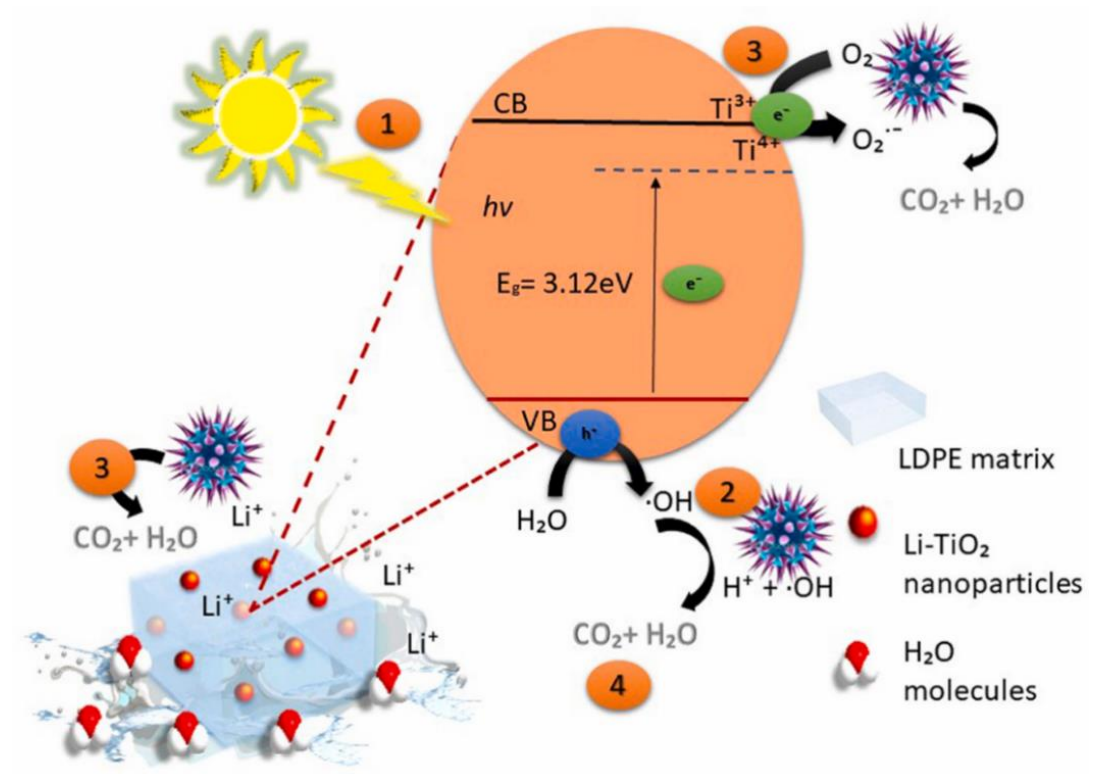

Figure 5. The antimicrobial mechanism of the heterostructured nanocomposites of $\mathrm{Li}^{-\mathrm{TiO}_{2} / \mathrm{LDPE}}$ against S. aureus. Abbreviation: valence band: VB; conduction band: CB. Reproduced with permission from ref. [83]. Copyright (C) 2019, Elsevier.

The heterostructured nanomaterials of copper-doped $\mathrm{TiO}_{2}\left(\mathrm{Cu}-\mathrm{TiO}_{2}\right)$ have been applied as an antibacterial agent against $E$. coli and $S$. aureus with visible light illumination [84]. By utilizing dopant of oxidizing copper, $\mathrm{Cu}-\mathrm{TiO}_{2}$ nanomaterials revealed the increase of absorption in visible region and the band gap of $\mathrm{Cu}-\mathrm{TiO}_{2}$ nanomaterials was reduced to $2.8 \mathrm{eV}$. The photo-induced bactericidal activity of $\mathrm{Cu}-\mathrm{TiO}_{2}$ heterostructured nanomaterial have been respectively executed with and without visible light illumination (Figure 6). Without photocatalysts, the E. coli and S. aureus bacteria continued growing under light and dark conditions. Moreover, in the dark, the $\mathrm{Cu}-\mathrm{TiO}_{2}$ nanomaterials, anatase $\mathrm{TiO}_{2}$ nanoparticles and rutile $\mathrm{TiO}_{2}$ nanoparticles had no significant bacterial growth after culture for $90 \mathrm{~min}$. After visible light irradiation for $30 \mathrm{~min}$, the $\mathrm{Cu}-\mathrm{TiO}_{2}$ nanomaterials had achieved $99.9999 \%$ bacterial reduction. However, to obtain $99.9999 \%$ bacterial reduction, both anatase and rutile $\mathrm{TiO}_{2}$ nanoparticles required light irradiation for 60 and $90 \mathrm{~min}$, respectively. In comparison with anatase and rutile $\mathrm{TiO}_{2}$ nanoparticles, $\mathrm{Cu}-\mathrm{TiO}_{2}$ nanomaterials showed better antibacterial activity. The results indicate that the dopant of $\mathrm{Cu}$ in $\mathrm{Cu}-\mathrm{TiO}_{2}$ nanomaterials may improve the visible absorption efficiency to enhance bacterial inactivation. After the absorption of light, the charge carriers formed on $p-n$ junction of $\mathrm{Cu}_{2} \mathrm{O}-\mathrm{TiO}_{2}$ nanomaterials and then reacted with the oxygen and water incorporated on the surface of $\mathrm{Cu}_{2} \mathrm{O}-\mathrm{TiO}_{2}$ nanomaterials to become radicals to disrupt bacterial membrane and cause bacterial gene alteration to kill bacteria. 


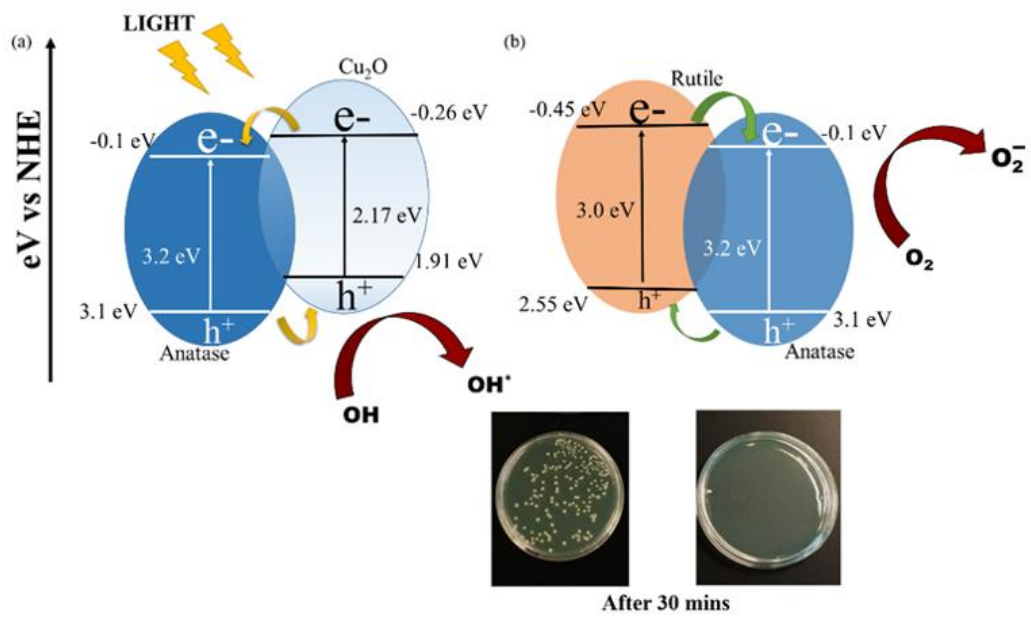

Figure 6. Mechanisms of photocatalytic antibacterial activity (a) p-n junction by heterostructured $\mathrm{Cu}_{2} \mathrm{O}$ and $\mathrm{TiO}_{2}$ (b) Type-2 heterostructures of anatase and rutile $\mathrm{TiO}_{2}$ nanoparticles. Images of $S$. aureus colonies in the agar plates with (right) and without (left) $\mathrm{Cu}-\mathrm{TiO}_{2}$ nanomaterials after $30 \mathrm{~min}$ illumination. Reproduced with permission from ref. [84]. Copyright @ 2018, MDPI.

The thin film of photocatalyst of $\alpha-\mathrm{Fe}_{2} \mathrm{O}_{3}$ nanograin chains incorporated with anatase $\mathrm{TiO}_{2}$ nanolayer $\left(\mathrm{TiO}_{2} / \mathrm{Fe}_{2} \mathrm{O}_{3}\right)$ exhibited bactericidal activity against $E$. coli with visible light illumination [85]. The bacterial inactivation of the anatase $\mathrm{TiO}_{2}, \alpha-\mathrm{Fe}_{2} \mathrm{O}_{3}$ and $\mathrm{TiO}_{2} / \alpha-\mathrm{Fe}_{2} \mathrm{O}_{3}$ thin films has been studied in the bacterial model of $E$. coli under visible light illumination, with and without $\mathrm{H}_{2} \mathrm{O}_{2}$ (Figure 7). As shown in Figure 7, $\mathrm{TiO}_{2} / \alpha-\mathrm{Fe}_{2} \mathrm{O}_{3}$ thin film reveals the reduction rate of $2.6 \times 10^{-2}$ and $6.5 \times 10^{-2}$ min $^{-1}$ without and with $\mathrm{H}_{2} \mathrm{O}_{2}$ for E. coil, reflecting a better antibacterial activity than anatase $\mathrm{TiO}_{2}$ and bare $\alpha-\mathrm{Fe}_{2} \mathrm{O}_{3}$ thin film. The better bacterial inactivity of $\mathrm{TiO}_{2} / \alpha-\mathrm{Fe}_{2} \mathrm{O}_{3}$ thin film may be ascribed to the heterostructure of $\mathrm{TiO}_{2} / \mathrm{Fe}_{2} \mathrm{O}_{3}$. Through visible light irradiation onto $\mathrm{TiO}_{2} / \mathrm{Fe}_{2} \mathrm{O}_{3}$ heterojunction, electrons located in the valence band of $\mathrm{Fe}_{2} \mathrm{O}_{3}$ may be excited to the conduction band-and then, electrons located in the valence band of $\mathrm{TiO}_{2}$ may be driven into the valance band of $\mathrm{Fe}_{2} \mathrm{O}_{3}$. Therefore, the anatase $\mathrm{TiO}_{2}$ nanolayer coated with $\mathrm{TiO}_{2} / \alpha-\mathrm{Fe}_{2} \mathrm{O}_{3}$ thin film could be applied to enhance of the photocatalytic capability of the coated $\mathrm{Fe}_{2} \mathrm{O}_{3}$ nanograins. The anatase $\mathrm{TiO}_{2}$ nanolayer could increase the production of $\mathrm{Fe}^{2+}$ to react with the $\mathrm{H}_{2} \mathrm{O}_{2}$ for the generation of $\mathrm{OH}$ radicals resulted from the reactions of Fenton and photo-Fenton. Furthermore, water or hydroxyl groups adsorbed onto anatase $\mathrm{TiO}_{2}$ nanolayer may be used to trap the holes to produce ROS of hydroxyl radicals for the bactericidal activity enhancement to bacteria.

Recent developments of implants have focused on the design of their surface in terms of bacterial inactivation and reusable feasibility. The dopants nitrogen $(\mathrm{N})$ and bismuth $(\mathrm{Bi})$ in $\mathrm{TiO}_{2}-$ incorporated with the plasma electrolytic oxidation (PEO) — revealed light-induced antibacterial activity and re-activation potential [86]. With the dopant $\mathrm{Bi}$, the band gap energy of $\mathrm{TiO}_{2}$ was shifted to the visible light region. To confirm the in vitro antibacterial effect, the photocatalysts of $\mathrm{TiO}_{2}$ coated with urea (Urea- $\mathrm{TiO}_{2}$ group), $\mathrm{TiO}_{2}$ doped with $\mathrm{Bi}\left(\mathrm{Bi}-\mathrm{TiO}_{2}\right.$ group) and $\mathrm{TiO}_{2}$ co-doped with urea and $\mathrm{Bi}$ (Urea, Bi- $\mathrm{TiO}_{2}$ group) were applied as antibacterial agents for two biofilms, including Streptococcus sanguinis and Actinomyces naeslundii. The results of the in vitro antibacterial tests indicated that the urea, $\mathrm{Bi}-\mathrm{TiO}_{2}$ group presented the best performance in bactericidal activity with visible light illumination. With a synergistic effect of $\mathrm{N}$ and $\mathrm{Bi}$ under visible light illumination, the narrowed band gap of $\mathrm{Bi}_{2} \mathrm{O}_{3}$ combined with $\mathrm{TiO}_{2}$ could facilitate electrons migration from the valence band to the conduction band located in $\mathrm{TiO}_{2}$ and $\mathrm{Ti}^{3+}$ sites to react with $\mathrm{O}_{2}$ to form $\cdot \mathrm{O}_{2}{ }^{-}$and also $\cdot \mathrm{OH}$ radical could be produced according to the reaction of holes located in the valence band of $\mathrm{TiO}_{2}$ with $\mathrm{H}_{2} \mathrm{O}$ (Figure 8). The $\mathrm{ROS}$ of $\cdot \mathrm{O}_{2}{ }^{-}$and $\cdot \mathrm{OH}$ may induce damage of bacterial wall, membrane, organelles, proteins and genetic materials (DNA, RNA) to cause death of bacteria. 


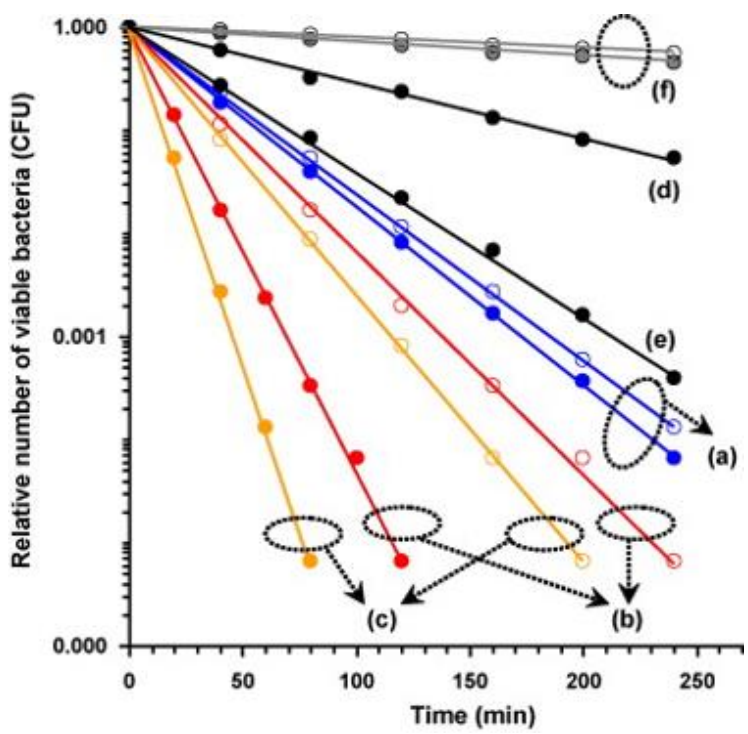

Figure 7. Relative number of viable E. coli on surface of (a) the anatase $\mathrm{TiO}_{2}$ (b) the $\alpha-\mathrm{Fe}_{2} \mathrm{O}_{3}$ and (c) the $\mathrm{TiO}_{2} / \mathrm{Fe}_{2} \mathrm{O}_{3}$ thin films under visible light irradiation. (d) The $\alpha-\mathrm{Fe}_{2} \mathrm{O}_{3}$ and (e) the $\mathrm{TiO}_{2} / \mathrm{Fe}_{2} \mathrm{O}_{3}$ thin films without light illumination. (f) Control samples containing the solution without $\mathrm{H}_{2} \mathrm{O}_{2}(\bigcirc)$ and with $\mathrm{H}_{2} \mathrm{O}_{2}(\bullet)$ with light illumination. The black circles indicated the samples of $\mathrm{a}, \mathrm{b}, \mathrm{c}$ and $\mathrm{f}$ containing the solution without $\mathrm{H}_{2} \mathrm{O}_{2}(\bigcirc)$ and with $\mathrm{H}_{2} \mathrm{O}_{2}(\bullet)$ with light illumination. Reproduced with permission from ref. [85]. Copyright (C) 2009, Elsevier.

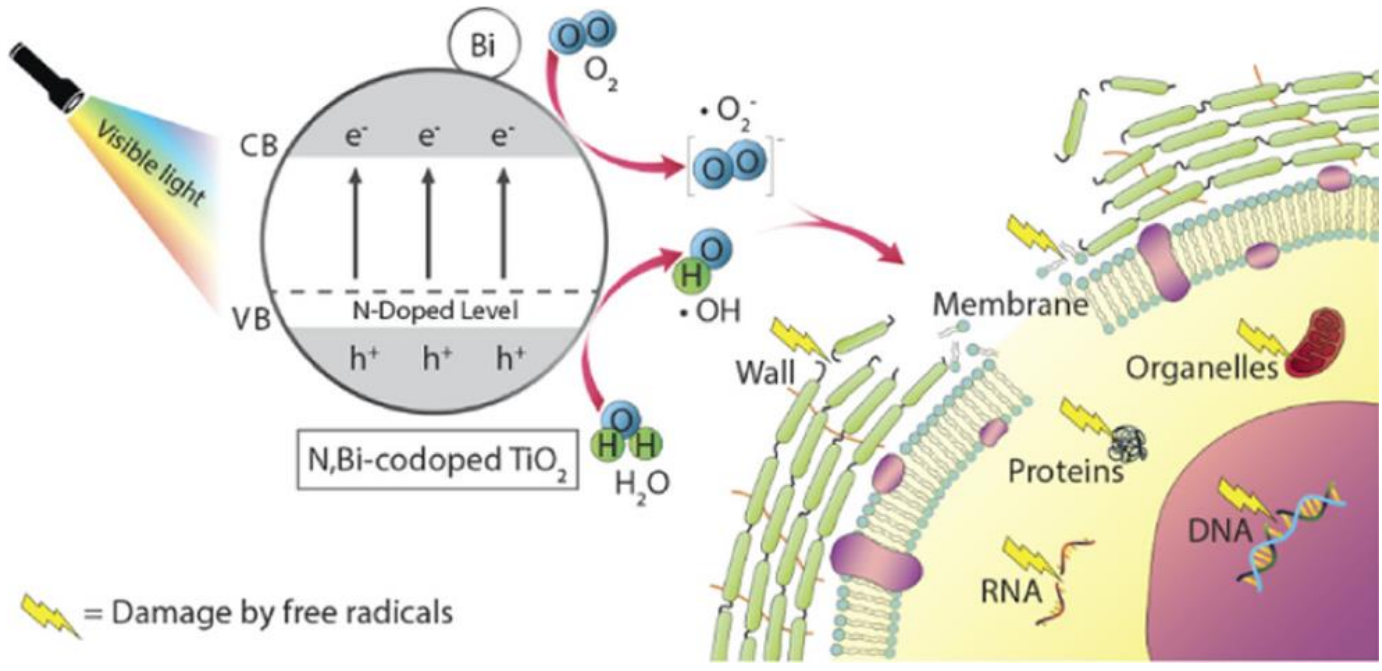

Figure 8. Schematic illustration of light-induced antibacterial mechanism of $\mathrm{N}, \mathrm{Bi}$-codoped $\mathrm{TiO}_{2}$ photocatalysts. Bacterial DNA should locate in cytoplasm. Reproduced with permission from ref. [86]. Copyright (C) 2019, American Chemical Society.

In recent times, nanocomposites of chitosan films containing melon/ $/ \mathrm{TiO}_{2}\left(\mathrm{CTS} / \mathrm{MTiO}_{2}\right)$ have been applied for self-cleaning of malachite green and light-induced antibacterial surfaces of $S$. aureus under light irradiation [87]. As the most common graphitic carbon nitride material $\left(\mathrm{g}-\mathrm{C}_{3} \mathrm{~N}_{4}\right)$, melon is a visible-light harvesting molecule. The bacterial inactivation of $\mathrm{CTS} / \mathrm{MTiO}_{2}$ nanocomposites was assessed against $S$. aureus with light illumination (Figure 9). After incubated with $S$. aureus for $3 \mathrm{~h}$, $\mathrm{CTS} / \mathrm{P} 25, \mathrm{CTS} / \mathrm{MTiO}_{2}$ and CTS have revealed different antibacterial activities with and without actinic light irradiations as shown in Figure 9a. Furthermore, in Figure 9b, antibacterial mechanism of $\mathrm{CTS} / \mathrm{MTiO}_{2}$ films has been explained under actinic light irradiation. For the control experiments, chitosan and CTS/P25 films showed no significant bacterial inactivation with and without actinic light 
irradiation for $3 \mathrm{~h}$. On the other hand, CTS/MTiO 2 films exhibited an antibacterial rate $99 \%$ of $S$. aureus after $3 \mathrm{~h}$ of actinic light irradiation. Previous studies indicated that chitosan films combined neat $\mathrm{TiO}_{2}$ nanoparticles exhibited a bactericidal efficiency of $99.9 \%$ for E. coli under light irradiation for $4 \mathrm{~h}$. However, under actinic light irradiation for $4 \mathrm{~h}$, chitosan films combined neat $\mathrm{TiO}_{2}$ nanoparticles had no antibacterial activity for $S$. aureus. In this aspect, $\mathrm{CTS} / \mathrm{MTiO}_{2}$ films had superior antibacterial activity for $S$. aureus. For the antibacterial mechanism, $\mathrm{CTS} / \mathrm{MTiO} 2$ films were induced for the formation of ROS such as $\cdot \mathrm{OH},{ }^{1} \mathrm{O}_{2}, \cdot \mathrm{O}_{2}{ }^{-}$and $\mathrm{H}_{2} \mathrm{O}_{2}$ to damage bacterial cell membrane with actinic light irradiation.

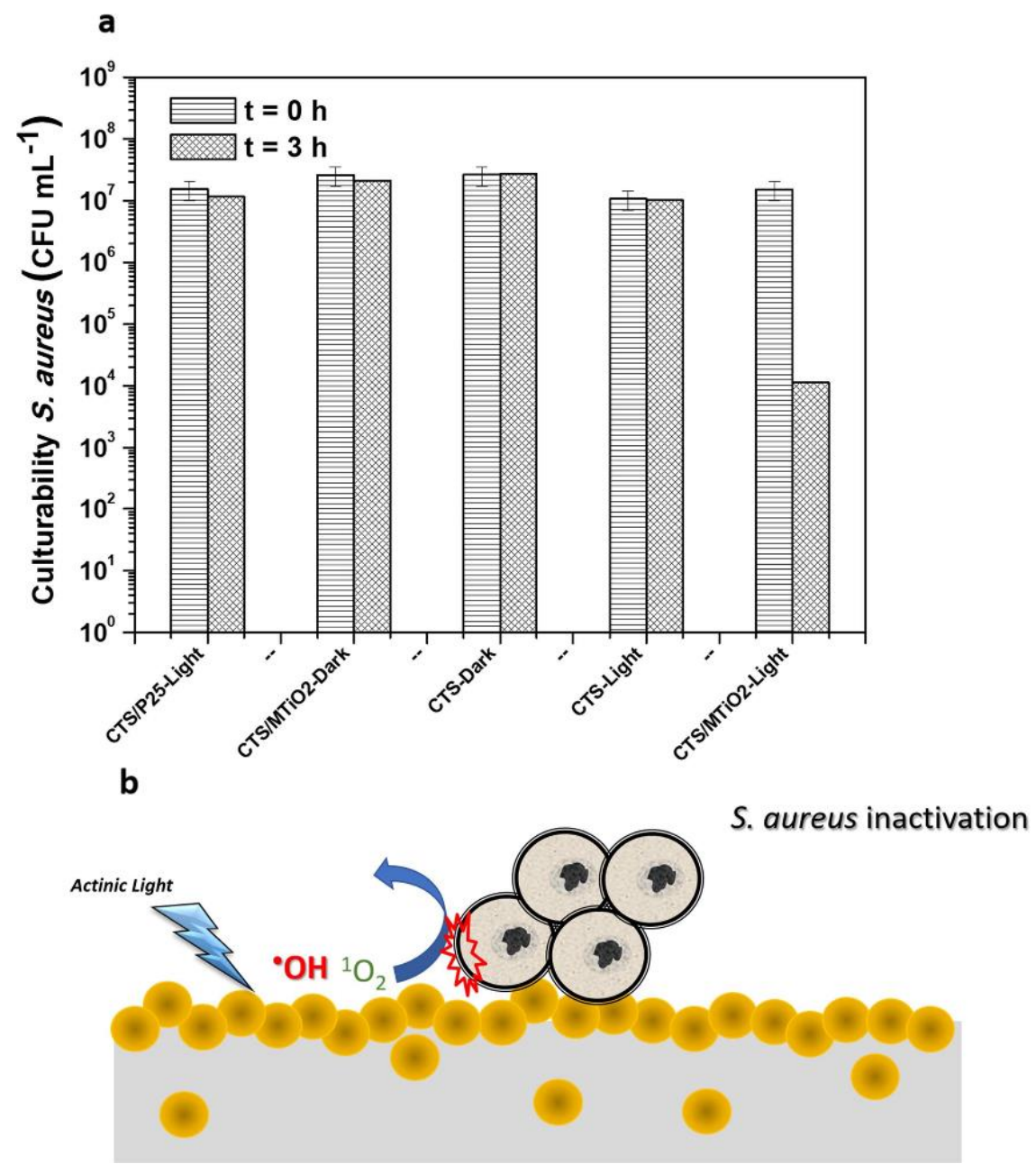

Figure 9. (a) Bacterial culturability of S. aureus with and without actinic light irradiation. (b) Antibacterial mechanism of $\mathrm{CTS} / \mathrm{MTiO}_{2}$ films under actinic light irradiation. Reproduced with permission from ref. [87]. Copyright (C) 2019, Elsevier.

Nanocomposites of uniform $\mathrm{TiO}_{2}$ nanoparticles and graphene sheets $\left(\mathrm{TiO}_{2} / \mathrm{GSs}\right)$ have been fabricated via a facile redox reaction for antibacterial applications [88-93]. $\mathrm{TiO}_{2}$ nanoparticles were anchored on the surfaces of GSs by chemical bonds. Moreover, nanocomposites of $\mathrm{TiO}_{2} / \mathrm{GSs}_{\text {exhibited }}$ broad absorption region from UV light to visible light. The photocatalysts of $\mathrm{TiO}_{2} / \mathrm{GS}$ sere used to kill E. coli under visible light illumination. Uniform $\mathrm{TiO}_{2}$ nanoparticles showed lower antibacterial capability in comparison with $\mathrm{TiO}_{2} /$ GSs nanocomposites due to their large band gap, resulting in very low light absorption in the visible region (Figure 10). UV-Vis absorption spectra of pure $\mathrm{TiO}_{2}$ nanoparticles, $\mathrm{TiO}_{2} / \mathrm{GSs}$ with $\mathrm{TiO}_{2} / 1.4 \mathrm{wt} \%$, $\mathrm{TiO}_{2} / \mathrm{GSs}$ with $\mathrm{TiO}_{2} / 4.2 \mathrm{wt} \%$ and $\mathrm{TiO}_{2} / \mathrm{GSs}$ with $\mathrm{TiO} / 7$ $\mathrm{wt} \%$ have shown in Figure 10a. Under visible light illumination for $12 \mathrm{~h}$, viabilities of E. coli incubated with various $\mathrm{TiO}_{2}$-based nanocomposites have been respectively calculated as shown in Figure $10 \mathrm{~b}$. Under visible light illumination, the nanocomposites of $\mathrm{TiO}_{2} / \mathrm{GSs}$ with $\mathrm{TiO}_{2} / 4.2 \mathrm{wt} \%$ revealed the best 
antibacterial activity in comparison with $\mathrm{TiO}_{2} / \mathrm{GSs}$ with various weight ratios, including $\mathrm{TiO}_{2} / 1.4 \mathrm{wt} \%$ and $\mathrm{TiO}_{2} / 7 \mathrm{wt} \%$. The superior antibacterial activity of $\mathrm{TiO}_{2} / \mathrm{GSs}$ nanocomposites may be explained by the increase of light absorption in visible region and effective separation of photo-generated electron-hole pairs because graphene could be applied as an electron acceptor and transporter. With the effective separation of light-generated pairs of electrons and holes, $\mathrm{TiO}_{2} / \mathrm{GS}$ s nanocomposites may produce more $\mathrm{ROS}$, including $\cdot \mathrm{OH}$ and $\cdot \mathrm{O}_{2}{ }^{-}$for disinfection activity of $E$. coli. For the nanocomposites of $\mathrm{TiO}_{2} / \mathrm{GSs}$ with $\mathrm{TiO}_{2} / 7 \mathrm{wt} \%$, the decrease of antibacterial activity may be ascribed to that the active $\mathrm{TiO}_{2}$ nanoparticles were covered by a large number of GSs, forming a shield of active sites on $\mathrm{TiO}_{2}$ nanoparticles.

a

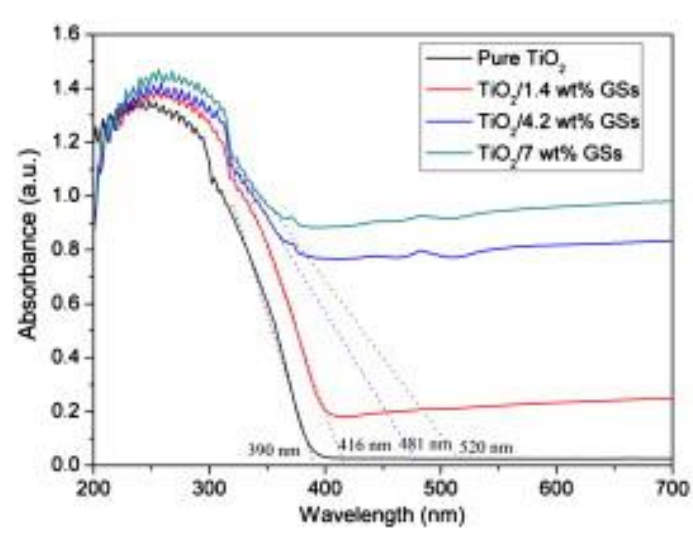

b

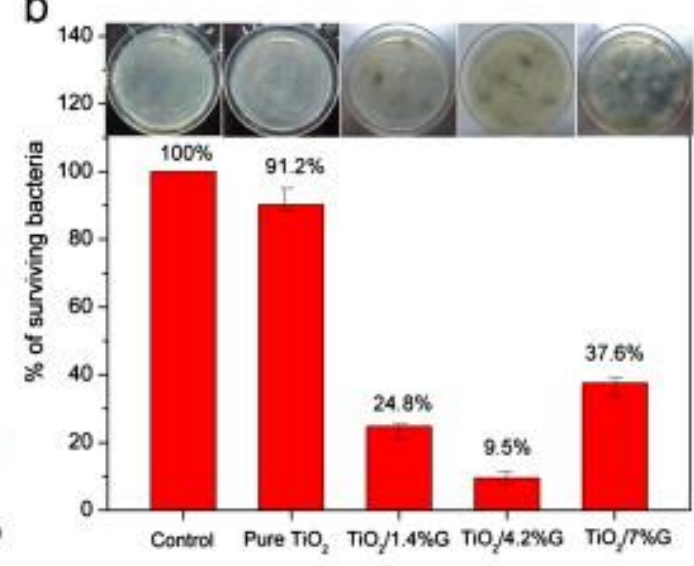

Figure 10. (a) UV-Vis absorption spectra of pure $\mathrm{TiO}_{2}$ nanoparticles, $\mathrm{TiO}_{2} / \mathrm{GSs}$ with $\mathrm{TiO}_{2} / 1.4 \mathrm{wt} \%$, $\mathrm{TiO}_{2} / \mathrm{GSs}$ with $\mathrm{TiO}_{2} / 4.2 \mathrm{wt} \%$ and $\mathrm{TiO}_{2} / \mathrm{GSs}$ with $\mathrm{TiO}_{2} / 7 \mathrm{wt} \%$. (b) Viabilities of $E$. coli incubated with various $\mathrm{TiO}_{2}$-based nanocomposites under visible light illumination for $12 \mathrm{~h}$. The insets are the corresponding photographs of agar plates. Reproduced with permission from ref. [88]. Copyright (C) 2013, Elsevier.

Heterostructured nanocomposites of reduced graphene oxide and cuprous oxide $\left(\mathrm{rGO}-\mathrm{Cu}_{2} \mathrm{O}\right)$ have been prepared by the reduction of copper sulfate on graphene oxide for long-term antibacterial activities [94]. The P-type semiconductor of $\mathrm{Cu}_{2} \mathrm{O}$ may easily separate its electron-hole pairs under light condition. In this study, the fresh $\mathrm{rGO}-\mathrm{Cu}_{2} \mathrm{O}$ nanocomposites generated more ROS compared to that of fresh $\mathrm{rGO}$ and $\mathrm{Cu}_{2} \mathrm{O}$ (Figure 11). The results indicated that the separation performance of photo-excited charges of $\mathrm{Cu}_{2} \mathrm{O}$ may be distinctly increased by the combination of $\mathrm{Cu}_{2} \mathrm{O}$ and rGO due to the improvement of interfacial charge transfer between $\mathrm{Cu}_{2} \mathrm{O}$ and $\mathrm{rGO}$. The ROS antibacterial mechanism of $\mathrm{rGO}-\mathrm{Cu}_{2} \mathrm{O}$ nanocomposites may be attributed to that the light-induced electrons were delivered from $\mathrm{Cu}_{2} \mathrm{O}$ to $\mathrm{rGO}$ to eliminate the recombination of the pairs of electrons and holes [95]. The photo-excited electrons and holes from $\mathrm{Cu}_{2} \mathrm{O}$ may be used for disinfection of bacteria [96]. Furthermore, rGO have played an important role for the acceptance of light-induced electrons from $\mathrm{Cu}_{2} \mathrm{O}$ to provide efficient charge transfer between the heterostructured nanocomposites of $\mathrm{rGO}-\mathrm{Cu} \mathrm{u}_{2} \mathrm{O}$ and bacteria. The photo-excited electrons and holes may create intracellular ROS such as $\mathrm{H}_{2} \mathrm{O}_{2}, \cdot \mathrm{OH}$ and $\cdot \mathrm{O}_{2}{ }^{-}$. Eventually, the active substances of ROS could cause damage of nucleic acids, inactivation of intracellular protein, disability of the mitochondria and destruction of bacterial membrane. 


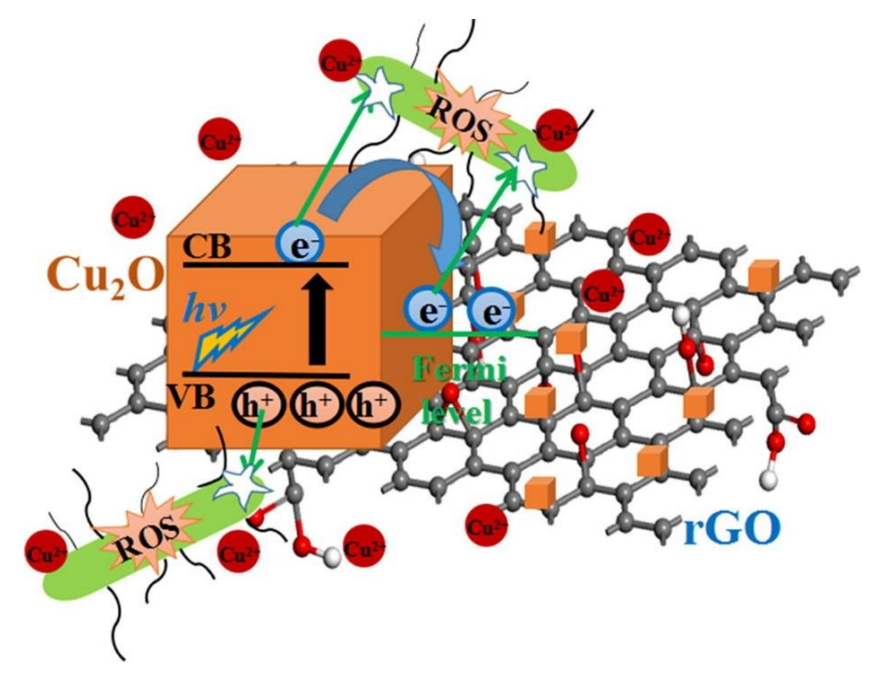

Figure 11. Reactive oxygen species (ROS) production caused by the heterostructured nanocomposites rGO- $\mathrm{Cu}_{2} \mathrm{O}$ under light illumination. Reproduced with permission from ref. [94]. Copyright (C) 2019, Elsevier.

Zinc oxide-selenium ( $\mathrm{ZnO}-\mathrm{Se}$ ) heterojunction nanocomposites have been fabricated as antibacterial agents for S. aureus [97]. For the control, $\mathrm{ZnO}$ nanoparticles showed the zone of inhibition as $3.0 \mathrm{~cm}$ for $S$. aureus with visible light illumination. In the contrast, $\mathrm{ZnO}$-Se nanocomposites revealed outstanding antibacterial activity with a zone of inhibition as $5 \mathrm{~cm}$ for $S$. aureus with visible light illumination. Furthermore, the bactericidal property of $\mathrm{ZnO}-\mathrm{Se}$ nanocomposites remained for few days to inhibit the growth of $S$. aureus. The enhancement of antibacterial activity of $\mathrm{ZnO}$-Se nanocomposites could be attributed to the increase of light-harvesting capability for sustainable production of ROS to kill S. aureus (Figure 12). To investigate the role of ROS in the antibacterial mechanism, electron spin resonance (ESR) was utilized to assess the types of ROS production from $\mathrm{ZnO}$-Se nanocomposites. The results of ESR experiments demonstrated that ZnO-Se nanocomposite may produce ROS, including singlet oxygen and reactive $\mathrm{OH}$ species. Overall, the $\mathrm{ZnO}$-Se heterojunction nanocomposites had long term enhancement of their antibacterial activity with visible light illumination and therefore, may be a potential antibacterial agent.

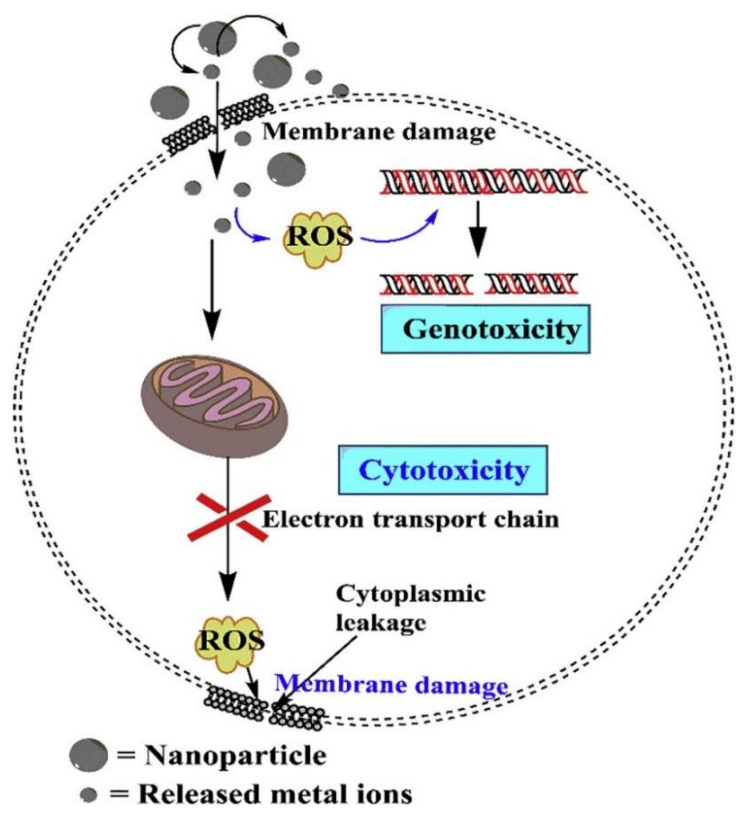

Figure 12. Antibacterial mechanisms of $\mathrm{ZnO}-S e$ nanocomposites with visible light illumination. Reproduced with permission from ref. [97]. Copyright (C 2020, Elsevier. 


\section{Challenges and Opportunities}

In this review, we have compiled recent investigations of heterostructured nanomaterials as light-activated antibacterial agents in applications such as medicine, food safety, water sterilization and the textile industry (Table 1). These investigations have demonstrated that heterostructured nanomaterials may be high-performance antibacterial agents due to their synergistic effects under light irradiation. With synergistic effects, heterostructured nanomaterials exhibited excellent antibacterial activities based on the increase of ROS generation under light irradiation. Furthermore, the heterostructures of nanomaterials also inhibited the recombination of photon-induced electron/hole pairs for the increase of ROS formation to kill bacteria. Although various heterostructured nanomaterials have been shown to be light-activated antimicrobial agents, their antibacterial activities still need to be improved. For real clinical applications, the antibacterial efficiency of LAHNs should fit the requirement with a $4-\log (99.99 \%)$ reduction in bacterial viability, which is one of the leading causes of nosocomial infections in the world. The first challenge to enhance the antimicrobial activity of LAHNs is to increase their synergistic effects. The development of LAHNs with novel compositions would be recommended. The second challenge to improve antibacterial activity for light-activated antimicrobial agents is to combine with other optical properties. For example, the photothermal effect is also used to kill bacteria with light irradiation. Therefore, with ROS generation and photothermal effects, LAHNs may provide better antimicrobial activities. The third challenge for light-activated antimicrobial agents is to increase their biocompatibility for the clinic application. To date, the cytotoxicity of LAHNs is still too high for clinic tests. However, in vitro and in vivo studies of light-activated antimicrobial agents of heterostructured nanomaterials are a critical step for future clinic application. Overall, to realize the antibacterial agents of LAHNs, great efforts are still needed for the improvement of their antibacterial activities. With intensive studies, we believe that antibacterial agents of LAHNs can be utilized as the important antibacterial agents in the near future.

Table 1. Light-activated nanomaterials for antibacterial application in this review.

\begin{tabular}{|c|c|c|c|c|}
\hline Nanomaterials & Light harvester & Light Source & Bacteria & References \\
\hline $\mathrm{Ag}-\mathrm{TiO}_{2}$ & $\mathrm{Ag}$ & UV light & B. subtilis and P. putida & [68] \\
\hline $\mathrm{TiO}_{2} / \mathrm{AgVO}_{3}$ & $\mathrm{AgVO}_{3}$ & visible light & E. coli & [75] \\
\hline $\mathrm{Ag} / \mathrm{TiO}_{2} /$ cellulose & $\mathrm{Ag}$ & UV light & E. coli & [81] \\
\hline Alginate/Au- $-\mathrm{TiO}_{2}$ & $\mathrm{Au}$ & visible light & S. aureus and E. coli & [82] \\
\hline $\mathrm{Li}^{-}-\mathrm{TiO}_{2} / \mathrm{LDPE}$ & $\mathrm{Li}$ & visible light & S. aureus & [83] \\
\hline $\mathrm{Cu}-\mathrm{TiO}_{2}$ & $\mathrm{Cu}$ & visible light & E. coli & [84] \\
\hline $\mathrm{TiO}_{2} / \alpha-\mathrm{Fe}_{2} \mathrm{O}_{3}$ & $\alpha-\mathrm{Fe}_{2} \mathrm{O}_{3}$ & visible light & E. coli & [85] \\
\hline $\mathrm{U}, \mathrm{Bi}-\mathrm{TiO}_{2}$ & $\mathrm{~N}$ and $\mathrm{Bi}$ & visible light & S. sanguinis and $A$. naeslundii & [86] \\
\hline $\mathrm{CTS} / \mathrm{MTiO}_{2}$ & melon & visible light & S. aureus & [87] \\
\hline $\mathrm{TiO}_{2} / \mathrm{GSs}$ & $\mathrm{TiO}_{2}$ & visible light & E. coli & [88] \\
\hline $\mathrm{rGO}-\mathrm{Cu}_{2} \mathrm{O}$ & $\mathrm{Cu}_{2} \mathrm{O}$ & sunlight & S. aureus and E. coli & [94] \\
\hline $\mathrm{ZnO}-\mathrm{Se}$ & $\mathrm{Se}$ & visible light & S. aureus & [97] \\
\hline
\end{tabular}

Funding: This work was supported by MOST 108-2113-M-038-003 and Taipei Medical University.

Conflicts of Interest: The authors declare no conflict of interest.

\section{References}

1. Luo, J.; Deng, W.; Yang, F.; Wu, Z.; Huang, M.; Gu, M. Gold nanoparticles decorated graphene oxide/nanocellulose paper for nir laser-induced photothermal ablation of pathogenic bacteria. Carbohydr. Polym. 2018, 198, 206-214. [CrossRef] [PubMed]

2. Teng, C.P.; Zhou, T.; Ye, E.; Liu, S.; Koh, L.D.; Low, M.; Loh, X.J.; Win, K.Y.; Zhang, L.; Han, M.Y. Effective targeted photothermal ablation of multidrug resistant bacteria and their biofilms with nir-absorbing gold nanocrosses. Adv. Healthc. Mater. 2016, 5, 2122-2130. [CrossRef] [PubMed] 
3. Wang, Y.-W.; Fu, Y.-Y.; Wu, L.-J.; Li, J.; Yang, H.-H.; Chen, G.-N. Targeted photothermal ablation of pathogenic bacterium, staphylococcus aureus, with nanoscale reduced graphene oxide. J. Mater. Chem. B 2013, 1, 2496-2501. [CrossRef]

4. Khan, S.A.; Singh, A.K.; Senapati, D.; Fan, Z.; Ray, P.C. Bio-conjugated popcorn shaped gold nanoparticles for targeted photothermal killing of multiple drug resistant salmonella dt104. J. Mater. Chem. 2011, 21, 17705-17709. [CrossRef]

5. Magiorakos, A.P.; Srinivasan, A.; Carey, R.B.; Carmeli, Y.; Falagas, M.E.; Giske, C.G.; Harbarth, S.; Hindler, J.F.; Kahlmeter, G.; Olsson-Liljequist, B.; et al. Multidrug-resistant, extensively drug-resistant and pandrug-resistant bacteria: An international expert proposal for interim standard definitions for acquired resistance. Clin. Microbiol. Infect. 2012, 18, 268-281. [CrossRef]

6. O'Connell, K.M.G.; Hodgkinson, J.T.; Sore, H.F.; Welch, M.; Salmond, G.P.C.; Spring, D.R. Combating multidrug-resistant bacteria: Current strategies for the discovery of novel antibacterials. Angew. Chem. Int. Ed. 2013, 52, 10706-10733. [CrossRef]

7. Simoes, M.; Bennett, R.N.; Rosa, E.A.S. Understanding antimicrobial activities of phytochemicals against multidrug resistant bacteria and biofilms. Nat. Prod. Rep. 2009, 26, 746-757. [CrossRef]

8. Tacconelli, E.; Cataldo, M.A.; Dancer, S.J.; De Angelis, G.; Falcone, M.; Frank, U.; Kahlmeter, G.; Pan, A.; Petrosillo, N.; Rodriguez-Bano, J.; et al. Escmid guidelines for the management of the infection control measures to reduce transmission of multidrug-resistant gram-negative bacteria in hospitalized patients. Clin. Microbiol. Infect. 2014, 20, 1-55. [CrossRef]

9. Worthington, R.J.; Melander, C. Combination approaches to combat multidrug-resistant bacteria. Trends Biotechnol. 2013, 31, 177-184. [CrossRef]

10. Lam, S.J.; O’Brien-Simpson, N.M.; Pantarat, N.; Sulistio, A.; Wong, E.H.H.; Chen, Y.Y.; Lenzo, J.C.; Holden, J.A.; Blencowe, A.; Reynolds, E.C.; et al. Combating multidrug-resistant gram-negative bacteria with structurally nanoengineered antimicrobial peptide polymers. Nat. Microbiol. 2016, 1, 16162. [CrossRef]

11. Hopkins, K.L.; Davies, R.H.; Threlfall, E.J. Mechanisms of quinolone resistance in escherichia coli and salmonella: Recent developments. Int. J. Antimicrob. Agents 2005, 25, 358-373. [CrossRef] [PubMed]

12. Percival, S.L.; Bowler, P.G.; Russell, D. Bacterial resistance to silver in wound care. J. Hosp. Infect. 2005, 60, 1-7. [CrossRef] [PubMed]

13. Sabuncu, E.; David, J.; Bernède-Bauduin, C.; Pépin, S.; Leroy, M.; Boëlle, P.-Y.; Watier, L.; Guillemot, D. Significant reduction of antibiotic use in the community after a nationwide campaign in france, 2002-2007. PLoS Med. 2009, 6, e1000084. [CrossRef] [PubMed]

14. de Kraker, M.E.; Stewardson, A.J.; Harbarth, S. Will 10 million people die a year due to antimicrobial resistance by 2050? PLoS Med. 2016, 13, e1002184. [CrossRef]

15. Li, X.N.; Robinson, S.M.; Gupta, A.; Saha, K.; Jiang, Z.W.; Moyano, D.F.; Sahar, A.; Riley, M.A.; Rotello, V.M. Functional gold nanoparticles as potent antimicrobial agents against multi-drug-resistant bacteria. Acs Nano 2014, 8, 10682-10686. [CrossRef]

16. Rai, M.K.; Deshmukh, S.D.; Ingle, A.P.; Gade, A.K. Silver nanoparticles: The powerful nanoweapon against multidrug-resistant bacteria. J. Appl. Microbiol. 2012, 112, 841-852. [CrossRef]

17. Priyadarshini, S.; Gopinath, V.; Priyadharsshini, N.M.; MubarakAli, D.; Velusamy, P. Synthesis of anisotropic silver nanoparticles using novel strain, bacillus flexus and its biomedical application. Colloids Surf. B 2013, 102, 232-237. [CrossRef]

18. Morones, J.R.; Elechiguerra, J.L.; Camacho, A.; Holt, K.; Kouri, J.B.; Ramirez, J.T.; Yacaman, M.J. The bactericidal effect of silver nanoparticles. Nanotechnology 2005, 16, 2346-2353. [CrossRef]

19. Marambio-Jones, C.; Hoek, E.M.V. A review of the antibacterial effects of silver nanomaterials and potential implications for human health and the environment. J. Nanopart. Res. 2010, 12, 1531-1551. [CrossRef]

20. Zuckerman, J.E.; Gritli, I.; Tolcher, A.; Heidel, J.D.; Lim, D.; Morgan, R.; Chmielowski, B.; Ribas, A.; Davis, M.E.; Yen, Y. Correlating animal and human phase ia/ib clinical data with calaa-01, a targeted, polymer-based nanoparticle containing sirna. Proc. Natl. Acad. Sci. USA 2014, 111, 11449-11454. [CrossRef]

21. Gonavelli, G.; Chang, C.C.; Ling, Y.C. Facile synthesis of smart magnetic graphene for safe drinking water: Heavy metal removal and disinfection control. ACS Sustain. Chem. Eng. 2013, 1, 462-472. [CrossRef]

22. Lian, H.Y.; Hu, M.; Liu, C.H.; Yamauchi, Y.; Wu, K.C.W. Highly biocompatible, hollow coordination polymer nanoparticles as cisplatin carriers for efficient intracellular drug delivery. Chem. Commun. 2012, 48, 5151-5153. [CrossRef] [PubMed] 
23. Yang, Y.H.; Liu, C.H.; Liang, Y.H.; Lin, F.H.; Wu, K.C.W. Hollow mesoporous hydroxyapatite nanoparticles (hmhanps) with enhanced drug loading and ph-responsive release properties for intracellular drug delivery. J. Mater. Chem. B 2013, 1, 2447-2450. [CrossRef]

24. Fang, J.Y.; Fang, C.L.; Liu, C.H.; Su, Y.H. Lipid nanoparticles as vehicles for topical psoralen delivery: Solid lipid nanoparticles (sln) versus nanostructured lipid carriers (NLC). Eur. J. Pharm. Biopharm. 2008, 70, 633-640. [CrossRef]

25. Fang, C.L.; Al-Suwayeh, S.A.; Fang, J.Y. Nanostructured lipid carriers (NLCS) for drug delivery and targeting. Recent Pat. Nanotechnol. 2013, 7, 41-55. [CrossRef]

26. Chen, Y.P.; Chen, C.T.; Hung, Y.; Chou, C.M.; Liu, T.P.; Liang, M.R.; Chen, C.T.; Mou, C.Y. A new strategy for intracellular delivery of enzyme using mesoporous silica nanoparticles: Superoxide dismutase. J. Am. Chem. Soc. 2013, 135, 1516-1523. [CrossRef]

27. Li, C.H.; Shen, C.C.; Cheng, Y.W.; Huang, S.H.; Wu, C.C.; Kao, C.C.; Liao, J.W.; Kang, J.J. Organ biodistribution, clearance, and genotoxicity of orally administered zinc oxide nanoparticles in mice. Nanotoxicology 2012, 6, 746-756. [CrossRef]

28. Chen, M.C.; Mi, F.L.; Liao, Z.X.; Hsiao, C.W.; Sonaje, K.; Chung, M.F.; Hsu, L.W.; Sung, H.W. Recent advances in chitosan-based nanoparticles for oral delivery of macromolecules. Adv. Drug Deliv. Rev. 2013, 65, 865-879. [CrossRef]

29. Cho, E.C.; Chang-Jian, C.W.; Chen, H.C.; Chuang, K.S.; Zheng, J.H.; Hsiao, Y.S.; Lee, K.C.; Huang, J.H. Robust multifunctional superhydrophobic coatings with enhanced water/oil separation, self-cleaning, anti-corrosion, and anti-biological adhesion. Chem. Eng. J. 2017, 314, 347-357. [CrossRef]

30. Moon, R.J.; Martini, A.; Nairn, J.; Simonsen, J.; Youngblood, J. Cellulose nanomaterials review: Structure, properties and nanocomposites. Chem. Soc. Rev. 2011, 40, 3941-3994. [CrossRef]

31. Martin, C.R. Nanomaterials - a membrane-based synthetic approach. Science 1994, 266, 1961-1966. [CrossRef] [PubMed]

32. Bruce, P.G.; Scrosati, B.; Tarascon, J.M. Nanomaterials for rechargeable lithium batteries. Angew. Chem. Int. Ed. 2008, 47, 2930-2946. [CrossRef] [PubMed]

33. Chena, S.H.; Wu, C.H.; Fang, A.; Lin, C.K. Effects of adding different morphological carbon nanomaterials on supercapacitive performance of sol-gel manganese oxide films. Ceram. Int. 2016, 42, 4797-4805. [CrossRef]

34. Lin, C.A.J.; Chuang, W.K.; Huang, Z.Y.; Kang, S.T.; Chang, C.Y.; Chen, C.T.; Li, J.L.; Li, J.K.; Wang, H.H.; Kung, F.C.; et al. Rapid transformation of protein-caged nanomaterials into microbubbles as bimodal imaging agents. Acs Nano 2012, 6, 5111-5121. [CrossRef]

35. Le, D.; Wagner, F.; Takamiya, M.; Hsiao, I.L.; Alvaradejo, G.G.; Strahle, U.; Weiss, C.; Delaittre, G. Straightforward access to biocompatible poly(2-oxazoline)-coated nanomaterials by polymerization-induced self-assembly. Chem. Commun. 2019, 55, 3741-3744. [CrossRef]

36. Tian, J.; Leng, Y.H.; Zhao, Z.H.; Xia, Y.; Sang, Y.H.; Hao, P.; Zhan, J.; Li, M.C.; Liu, H. Carbon quantum dots/hydrogenated $\mathrm{TiO}_{2}$ nanobelt heterostructures and their broad spectrum photocatalytic properties under uv, visible, and near-infrared irradiation. Nano Energy 2015, 11, 419-427. [CrossRef]

37. Carbone, L.; Cozzoli, P.D. Colloidal heterostructured nanocrystals: Synthesis and growth mechanisms. Nano Today 2010, 5, 449-493. [CrossRef]

38. Mai, L.Q.; Yang, F.; Zhao, Y.L.; Xu, X.; Xu, L.; Luo, Y.Z. Hierarchical $\mathrm{MnMoO}_{4} / \mathrm{CoMoO}_{4}$ heterostructured nanowires with enhanced supercapacitor performance. Nat. Commun. 2011, 2, 381. [CrossRef]

39. Liu, R.; Duay, J.; Lee, S.B. Redox exchange induced $\mathrm{MnO}_{2}$ nanoparticle enrichment in poly(3,4-ethylenedioxythiophene) nanowires for electrochemical energy storage. Acs Nano 2010, 4, 4299-4307. [CrossRef]

40. Donega, C.D. Synthesis and properties of colloidal heteronanocrystals. Chem. Soc. Rev. 2011, 40, 1512-1546. [CrossRef]

41. Wang, Y.J.; Wang, Q.S.; Zhan, X.Y.; Wang, F.M.; Safdar, M.; He, J. Visible light driven type II heterostructures and their enhanced photocatalysis properties: A review. Nanoscale 2013, 5, 8326-8339. [CrossRef] [PubMed]

42. Kőrösi, L.; Bognár, B.; Horváth, M.; Schneider, G.; Kovács, J.; Scarpellini, A.; Castelli, A.; Colombo, M.; Prato, M.J.A.C.B.E. Hydrothermal evolution of pf-co-doped $\mathrm{TiO}_{2}$ nanoparticles and their antibacterial activity against carbapenem-resistant klebsiella pneumoniae. Appl. Catal. B Environ. 2018, 231, 115-122. [CrossRef]

43. Hu, C.; Lan, Y.Q.; Qu, J.H.; Hu, X.X.; Wang, A.M. Ag/AgBr $/ \mathrm{TiO}_{2}$ visible light photocatalyst for destruction of azodyes and bacteria. J. Phys. Chem. B 2006, 110, 4066-4072. [CrossRef] [PubMed] 
44. O'Donovan, P.; Perrett, C.M.; Zhang, X.H.; Montaner, B.; Xu, Y.Z.; Harwood, C.A.; McGregor, J.M.; Walker, S.L.; Hanaoka, F.; Karran, P. Azathioprine and uva light generate mutagenic oxidative DNA damage. Science 2005, 309, 1871-1874. [CrossRef]

45. Hopkinson, M.N.; Sahoo, B.; Li, J.L.; Glorius, F. Dual catalysis sees the light: Combining photoredox with organo-, acid, and transition-metal catalysis. Chem. Eur. J. 2014, 20, 3874-3886. [CrossRef]

46. Takahashi, S.; Badger, M.R. Photoprotection in plants: A new light on photosystem ii damage. Trends Plant Sci. 2011, 16, 53-60. [CrossRef]

47. Pelaez, M.; Nolan, N.T.; Pillai, S.C.; Seery, M.K.; Falaras, P.; Kontos, A.G.; Dunlop, P.S.M.; Hamilton, J.W.J.; Byrne, J.A.; O'Shea, K.; et al. A review on the visible light active titanium dioxide photocatalysts for environmental applications. Appl. Catal. B Environ. 2012, 125, 331-349. [CrossRef]

48. Li, Z.R.; Wakao, S.; Fischer, B.B.; Niyogi, K.K. Sensing and responding to excess light. Annu. Rev. Plant Biol. 2009, 60, 239-260. [CrossRef]

49. Sivaranjani, V.; Philominathan, P. Synthesize of titanium dioxide nanoparticles using moringa oleifera leaves and evaluation of wound healing activity. Wound Med. 2016, 12, 1-5. [CrossRef]

50. Lee, W.S.; Park, Y.-S.; Cho, Y.-K. Significantly enhanced antibacterial activity of $\mathrm{TiO}_{2}$ nanofibers with hierarchical nanostructures and controlled crystallinity. Analyst 2015, 140, 616-622. [CrossRef]

51. Jatoi, A.W.; Kim, I.S.; Ni, Q.-Q. Cellulose acetate nanofibers embedded with agnps anchored $\mathrm{TiO}_{2}$ nanoparticles for long term excellent antibacterial applications. Carbohydr. Polym. 2019, 207, 640-649. [CrossRef] [PubMed]

52. Hyde, G.K.; Stewart, S.M.; Scarel, G.; Parsons, G.N.; Shih, C.C.; Shih, C.M.; Lin, S.J.; Su, Y.Y.; Monteiro-Riviere, N.A.; Narayan, R.J. Atomic layer deposition of titanium dioxide on cellulose acetate for enhanced hemostasis. Biotechnol. J. 2011, 6, 213-223. [CrossRef] [PubMed]

53. Yang, K.C.; Zheng, J.H.; Chen, Y.L.; Lee, K.C.; Cho, E.C. Carboxyfullerene decorated titanium dioxide nanomaterials for reactive oxygen species scavenging activities. RSC Adv. 2016, 6, 53025-53033. [CrossRef]

54. Chen, X.B.; Liu, L.; Yu, P.Y.; Mao, S.S. Increasing solar absorption for photocatalysis with black hydrogenated titanium dioxide nanocrystals. Science 2011, 331, 746-750. [CrossRef]

55. Carp, O.; Huisman, C.L.; Reller, A. Photoinduced reactivity of titanium dioxide. Prog. Solid State Chem. 2004, 32, 33-177. [CrossRef]

56. Matsumoto, Y.; Murakami, M.; Shono, T.; Hasegawa, T.; Fukumura, T.; Kawasaki, M.; Ahmet, P.; Chikyow, T.; Koshihara, S.; Koinuma, H. Room-temperature ferromagnetism in transparent transition metal-doped titanium dioxide. Science 2001, 291, 854-856. [CrossRef]

57. Diebold, U. The surface science of titanium dioxide. Surf. Sci. Rep. 2003, 48, 53-229. [CrossRef]

58. Chen, X.; Mao, S.S. Titanium dioxide nanomaterials: Synthesis, properties, modifications, and applications. Chem. Rev. 2007, 107, 2891-2959. [CrossRef]

59. Wodka, D.; Bielanska, E.; Socha, R.P.; Elzbieciak-Wodka, M.; Gurgul, J.; Nowak, P.; Warszyński, P.; Kumakiri, I. Photocatalytic activity of titanium dioxide modified by silver nanoparticles. ACS Appl. Mater. Interfaces 2010, 2, 1945-1953. [CrossRef]

60. Gupta, K.; Singh, R.; Pandey, A.; Pandey, A. Photocatalytic antibacterial performance of $\mathrm{TiO}_{2}$ and Ag-doped $\mathrm{TiO}_{2}$ against s. Aureus. P. Aeruginosa and e. Coli. Beilstein J. Nanotechnol. 2013, 4, 345-351. [CrossRef]

61. Adams, L.K.; Lyon, D.Y.; Alvarez, P.J.J. Comparative eco-toxicity of nanoscale $\mathrm{TiO}_{2}, \mathrm{SiO}_{2}$, and $\mathrm{ZnO}$ water suspensions. Water Res. 2006, 40, 3527-3532. [CrossRef] [PubMed]

62. Wang, J.; Guo, Y.W.; Liu, B.; Jin, X.D.; Liu, L.J.; Xu, R.; Kong, Y.M.; Wang, B.X. Detection and analysis of reactive oxygen species (ros) generated by nano-sized $\mathrm{TiO}_{2}$ powder under ultrasonic irradiation and application in sonocatalytic degradation of organic dyes. Ultrason. Sonochem. 2011, 18, 177-183. [CrossRef] [PubMed]

63. Cho, M.; Chung, H.M.; Choi, W.Y.; Yoon, J.Y. Different inactivation behaviors of ms-2 phage and escherichia coli in $\mathrm{TiO}_{2}$ photocatalytic disinfection. Appl. Environ. Microbiol. 2005, 71, 270-275. [CrossRef] [PubMed]

64. Xiong, D.W.; Fang, T.; Yu, L.P.; Sima, X.F.; Zhu, W.T. Effects of nano-scale $\mathrm{TiO}_{2}, \mathrm{ZnO}$ and their bulk counterparts on zebrafish: Acute toxicity, oxidative stress and oxidative damage. Sci. Total Environ. 2011, 409, 1444-1452. [CrossRef] [PubMed]

65. Battin, T.J.; Kammer, F.V.D.; Weilhartner, A.; Ottofuelling, S.; Hofmann, T. Nanostructured TiO 2 : Transport behavior and effects on aquatic microbial communities under environmental conditions. Environ. Sci. Technol. 2009, 43, 8098-8104. [CrossRef] [PubMed] 
66. Kim, K.T.; Klaine, S.J.; Cho, J.; Kim, S.H.; Kim, S.D. Oxidative stress responses of daphnia magna exposed to $\mathrm{TiO}_{2}$ nanoparticles according to size fraction. Sci. Total Environ. 2010, 408, 2268-2272. [CrossRef]

67. George, S.; Pokhrel, S.; Ji, Z.X.; Henderson, B.L.; Xia, T.; Li, L.J.; Zink, J.I.; Nel, A.E.; Madler, L. Role of fe doping in tuning the band gap of $\mathrm{TiO}_{2}$ for the photo-oxidation-induced cytotoxicity paradigm. J. Am. Chem. Soc. 2011, 133, 11270-11278. [CrossRef]

68. Li, M.; Noriega-Trevino, M.E.; Nino-Martinez, N.; Marambio-Jones, C.; Wang, J.; Damoiseaux, R.; Ruiz, F.; Hoek, E.M. Synergistic bactericidal activity of $\mathrm{Ag}-\mathrm{TiO}_{2}$ nanoparticles in both light and dark conditions. Environ. Sci. Technol. 2011, 45, 8989-8995. [CrossRef]

69. Billings, E.A.; Lee, C.S.; Owen, K.A.; D'Souza, R.S.; Ravichandran, K.S.; Casanova, J.E. The adhesion gpcr bai1 mediates macrophage ros production and microbicidal activity against gram-negative bacteria. Sci. Signal. 2016, 9, ra14. [CrossRef]

70. Dharmaraja, A.T. Role of reactive oxygen species (ROS) in therapeutics and drug resistance in cancer and bacteria. J. Med. Chem. 2017, 60, 3221-3240. [CrossRef]

71. Waldeck, W.; Heidenreich, E.; Mueller, G.; Wiessler, M.; Toth, K.; Braun, K. Ros-mediated killing efficiency with visible light of bacteria carrying different red fluorochrome proteins. J. Photochem. Photobiol. B 2012, 109, 28-33. [CrossRef] [PubMed]

72. Ma, H.B.; Williams, P.L.; Diamond, S.A. Ecotoxicity of manufactured zno nanoparticles - a review. Environ. Pollut. 2013, 172, 76-85. [CrossRef]

73. Choi, O.; Hu, Z.Q. Size dependent and reactive oxygen species related nanosilver toxicity to nitrifying bacteria. Environ. Sci. Technol. 2008, 42, 4583-4588. [CrossRef]

74. Raghupathi, K.R.; Koodali, R.T.; Manna, A.C. Size-dependent bacterial growth inhibition and mechanism of antibacterial activity of zinc oxide nanoparticles. Langmuir 2011, 27, 4020-4028. [CrossRef] [PubMed]

75. Liu, B.; Han, X.; Mu, L.; Zhang, J.; Shi, H. TiO 2 nanospheres/AgVO $\mathrm{AV}_{3}$ quantum dots composite with enhanced visible light photocatalytic antibacterial activity. Mater. Lett. 2019, 253, 148-151. [CrossRef]

76. Ye, M.Y.; Zhao, Z.H.; Hu, Z.F.; Liu, L.Q.; Ji, H.M.; Shen, Z.R.; Ma, T.Y. 0d/2d heterojunctions of vanadate quantum dots/graphitic carbon nitride nanosheets for enhanced visible-light-driven photocatalysis. Angew. Chem. Int. Ed. 2017, 56, 8407-8411. [CrossRef]

77. Lin, X.; Xu, D.; Jiang, S.S.; Xie, F.; Song, M.S.; Zhai, H.J.; Zhao, L.N.; Che, G.B.; Chang, L.M. Graphitic carbon nitride nanocrystals decorated $\mathrm{AgVO}_{3}$ nanowires with enhanced visible-light photocatalytic activity. Catal. Commun. 2017, 89, 96-99. [CrossRef]

78. Klemm, D.; Heublein, B.; Fink, H.P.; Bohn, A. Cellulose: Fascinating biopolymer and sustainable raw material. Angew. Chem. Int. Ed. 2005, 44, 3358-3393. [CrossRef]

79. Yang, H.P.; Yan, R.; Chen, H.P.; Lee, D.H.; Zheng, C.G. Characteristics of hemicellulose, cellulose and lignin pyrolysis. Fuel 2007, 86, 1781-1788. [CrossRef]

80. Bledzki, A.K.; Gassan, J. Composites reinforced with cellulose based fibres. Prog. Polym. Sci. 1999, 24, 221-274. [CrossRef]

81. Li, Y.; Tian, J.; Yang, C.; Hsiao, B. Nanocomposite film containing fibrous cellulose scaffold and $\mathrm{Ag} / \mathrm{TiO} 2$ nanoparticles and its antibacterial activity. Polymers 2018, 10, 1052. [CrossRef] [PubMed]

82. Tang, S.; Wang, Z.; Li, P.; Li, W.; Li, C.; Wang, Y.; Chu, P. Degradable and photocatalytic antibacterial Au$\mathrm{TiO}_{2}$ /sodium alginate nanocomposite films for active food packaging. Nanomaterials 2018, 8, 930. [CrossRef] [PubMed]

83. Basiron, N.; Sreekantan, S.; Akil, H.M.; Saharudin, K.A.; Harun, N.H.; Mydin, R.B.S.; Seeni, A.; Rahman, N.R.A.; Adam, F.; Iqbal, A. Effect of $\mathrm{Li}^{-} \mathrm{TiO}_{2}$ nanoparticles incorporation in ldpe polymer nanocomposites for biocidal activity. Nano Struct. Nano Objects 2019, 19, 100359. [CrossRef]

84. Mathew, S.; Ganguly, P.; Rhatigan, S.; Kumaravel, V.; Byrne, C.; Hinder, S.; Bartlett, J.; Nolan, M.; Pillai, S. $\mathrm{Cu}$-doped $\mathrm{TiO}_{2}$ : Visible light assisted photocatalytic antimicrobial activity. Appl. Sci. 2018, 8, 2067. [CrossRef]

85. Akhavan, O.; Azimirad, R. Photocatalytic property of $\mathrm{Fe}_{2} \mathrm{O}_{3}$ nanograin chains coated by $\mathrm{TiO}_{2}$ nanolayer in visible light irradiation. Appl. Catal. A Gen. 2009, 369, 77-82. [CrossRef]

86. Nagay, B.E.; Dini, C.; Cordeiro, J.M.; Ricomini-Filho, A.P.; de Avila, E.D.; Rangel, E.C.; da Cruz, N.C.; Barao, V.A.R. Visible-light-induced photocatalytic and antibacterial activity of $\mathrm{TiO}_{2}$ codoped with nitrogen and bismuth: New perspective to control implant-biofilm-related disease. ACS Appl. Mater. Interfaces 2019, 11, 18186-18202. [CrossRef] 
87. Vélez-Peña, E.; Pérez-Obando, J.; Pais-Ospina, D.; Marín-Silva, D.A.; Pinotti, A.; Cánneva, A.; Donadelli, J.A.; Damonte, L.; Pizzio, L.R.; Osorio-Vargas, P. Self-cleaning and antimicrobial photo-induced properties under indoor lighting irradiation of chitosan films containing melon/ $\mathrm{TiO}_{2}$ composites. Appl. Surf. Sci. 2019, 508, 144895. [CrossRef]

88. Cao, B.; Cao, S.; Dong, P.; Gao, J.; Wang, J. High antibacterial activity of ultrafine $\mathrm{TiO}_{2} /$ graphene sheets nanocomposites under visible light irradiation. Mater. Lett. 2013, 93, 349-352. [CrossRef]

89. Kamat, P.V. Graphene-based nanoarchitectures. Anchoring semiconductor and metal nanoparticles on a two-dimensional carbon support. J. Phys. Chem. Lett. 2010, 1, 520-527. [CrossRef]

90. Xiang, Q.J.; Yu, J.G.; Jaroniec, M. Preparation and enhanced visible-light photocatalytic H-2-production activity of graphene/C3N4 composites. J. Phys. Chem. C 2011, 115, 7355-7363. [CrossRef]

91. Zhou, W.J.; Yin, Z.Y.; Du, Y.P.; Huang, X.; Zeng, Z.Y.; Fan, Z.X.; Liu, H.; Wang, J.Y.; Zhang, H. Synthesis of few-layer $\mathrm{MoS}_{2}$ nanosheet-coated $\mathrm{TiO}_{2}$ nanobelt heterostructures for enhanced photocatalytic activities. Small 2013, 9, 140-147. [CrossRef] [PubMed]

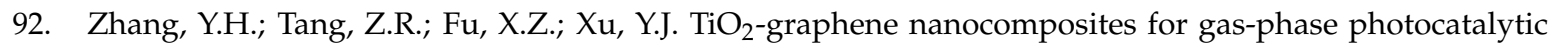
degradation of volatile aromatic pollutant: Is tio2-graphene truly different from other $\mathrm{TiO}_{2}$-carbon composite materials? Acs Nano 2010, 4, 7303-7314. [CrossRef] [PubMed]

93. Williams, G.; Seger, B.; Kamat, P.V. Tio2-graphene nanocomposites. Uv-assisted photocatalytic reduction of graphene oxide. Acs Nano 2008, 2, 1487-1491. [CrossRef] [PubMed]

94. Yang, Z.; Hao, X.; Chen, S.; Ma, Z.; Wang, W.; Wang, C.; Yue, L.; Sun, H.; Shao, Q.; Murugadoss, V. Long-term antibacterial stable reduced graphene oxide nanocomposites loaded with cuprous oxide nanoparticles. J. Colloid Interface Sci. 2019, 533, 13-23. [CrossRef] [PubMed]

95. Wei, Q.; Wang, Y.; Qin, H.; Wu, J.; Lu, Y.; Chi, H.; Yang, F.; Zhou, B.; Yu, H.; Liu, J. Construction of rGO wrapping octahedral $\mathrm{Ag}-\mathrm{Cu}_{2} \mathrm{O}$ heterostructure for enhanced visible light photocatalytic activity. Appl. Catal. $B$ Environ. 2018, 227, 132-144. [CrossRef]

96. Wang, R.; Kong, X.; Zhang, W.; Zhu, W.; Huang, L.; Wang, J.; Zhang, X.; Liu, X.; Hu, N.; Suo, Y. Mechanism insight into rapid photocatalytic disinfection of salmonella based on vanadate QDs-interspersed g-C3N4 heterostructures. Appl. Catal. B Environ. 2018, 225, 228-237. [CrossRef]

97. Ahmad, A.; Ullah, S.; Ahmad, W.; Yuan, Q.; Taj, R.; Khan, A.U.; Rahman, A.U.; Khan, U.A. Zinc oxide-selenium heterojunction composite: Synthesis, characterization and photo-induced antibacterial activity under visible light irradiation. J. Photochem. Photobiol. B 2020, 203, 111743. [CrossRef] 